\title{
ОПТИМІЗАЦЯ НАВЧАЛЬНОГО ПРОЦЕСУ 3 ОРГАНІЧНОЇ ХІМІЇ У СТУДЕНТІВ ФАРМАЦЕВТИЧНОГО ФАКУЛЬТЕТУ ЗАОЧНОЇ ФОРМИ НАВЧАННЯ
}

\author{
О. Ю. Воскобойнік
}

Запорізький державний медичний університет

\section{OPTIMIZATION OF EDUCATIONAL PROCESSES IN ORGANIC CHEMISTRY FOR STUDETS OF PHARMACEUTICAL FACULTY WITH EXTERNAL FORM OF EDUCATION}

\author{
O. Yu. Voskoboynik
}

\author{
Zaporizhzhia State Medical University
}

\begin{abstract}
У представленій роботі пропонуються нові напрямки оптимізації навчального процесу з органічної хімії для студентів фармацевтичного факультету заочної форми навчання. Запропоновано використання спеціалізованого програмного забезпечення та нових форм контролю знань.
\end{abstract}

The new approaches for optimization of educational process in organic chemistry for students of pharmaceutical faculty with external form of education were presented in the article. The usage of specialized software and new methods of education quality control were proposed.

Вступ. У теперішній час підготовка фахівців за спеціальністю “Фармація" (заочне навчання) вдало застосовується у більшості медичних (фармацевтичному) навчальних закладів III-IV рівнів акредитації. Особливою популярністю заочна форма навчання користується в абітурієнтів, які вже мають середню спеціальну освіту фармацевтичного спрямування та працюють за фахом, що пояснюється можливістю одночасного здобуття вищої освіти без відриву від практичної діяльності. В той самий час, в умовах вкрай динамічного розвитку усіх галузей знань, що входять до дисциплін навчального плану зі спеціальності “Фармація”, питання збереження високої якості освітніх послуг для студентів фармацевтичних факультетів заочної форми навчання стає все більш актуальним. Зокрема, на наш погляд, увагу привертає проблема необхідності створення якісної системи контролю знань студентів [1].

У представленій роботі ми поставили за мету розробити нові інструменти, що могли би вдосконалити підходи до навчального процесу з предмета "Органічна хімія" для студентів заочної форми навчання зі спеціальності “Фармація" на етапах самостійного опрацювання навчального матеріалу та контролю знань.
Основна частина. Як відомо, органічна хімія наука, що вивчає сполуки, які містять атоми Карбону, котрі сполучені з іншими елементами, їх структуpy, фізико-хімічні властивості, реакційну здатність тощо. Важливість даної дисципліни у становленні майбутнього фахівця в галузі фармації важко переоцінити, адже саме органічна хімія формує підгрунтя для вивчення таких предметів, як біологічна хімія, фармакологія, фармацевтична хімія, фармакогнозія, токсикологічна хімія тощо. Це додатково ускладнює навчальний процес, адже студенти мають не тільки оволодіти знаннями та практичними навичками 3 органічної хімії, але і вміти переносити здобуту інформацію на інші дисципліни, що вивчаються на старших курсах.

Якщо проаналізувати основні проблеми, що виникають у студентів при самостійному опрацюванні навчального матеріалу, слід одразу відокремити недостатню кількість літературних джерел, адже сучасний стан інформаційних технологій дозволяє одержати доступ до колосальної кількості інформації, зокрема до електронних версій сучасних підручників, методично-навчальних посібників, статей у наукових виданнях, лекційного матеріалу як у текстовому варіанті, так і у вигляді презентацій. Вказані матеріали

() О. Ю. Воскобойнік 
розміщені у мережі Internet як на комерційній основі, так і у вільному доступі. Незважаючи на це, у певної кількості студентів виникають проблеми при опрацюванні навчальних матеріалів. Можна зробити висновок, що одним із завдань викладача протягом установочної сесії є підбір літератури та інших джерел інформації під індивідуальні потреби окремо взятого студента. Також не виникає сумнівів у важливості методично правильної постановки алгоритму самостійного навчання, що має бути викладено у відповідному методичному матеріалі.

За нашими спостереженнями, у студентів заочної форми навчання виникають проблеми, пов'язані 3 відсутністю спеціального наглядного матеріалу, зокрема моделей молекул. Особливо це дається взнаки при вивченні стереохімії, механізмів реакцій в органічній хімії, хімії вуглеводів, гетероциклічних сполук та інших розділів, в яких важливо, щоб студент бачив у тривимірному просторі, як саме побудовані молекули та відбуваються ті чи інші явища. Вирішенням наведеної проблеми є використання в навчальному процесі програмних комплексів для молекулярного моделювання [2]. Кількість програмного забезпечення такого типу значно зросла в останній час, серед найбільш популярних слід відзначити Chem3D (ChemOffice) та Hyperchem. Наведені програми, окрім створення тривимірних молекулярних моделей, дозволяють розрахувати ряд параметрів, як молекули в цілому, так і атомів, з яких вона побудована. Необхідно зауважити, що Chem3D та Hyperchemє комерційним високовартісним програмним забезпеченням. Однак останнім часом розробляють все більше програмних засобів, що поширюють на безоплатній основі. Особливу увагу привертає до себе програма Avogadro. Це безкоштовне програмне забезпечення, що має дуже зручний та зрозумілий інтерфейс та широкий набір функцій, які дозволяють створювати тривимірні моделі й проводити оптимізацію геометрії молекул органічних сполук. Також зазначене програмне забезпечення дозволяє проводити пошук найбілыш енергетично вигідних конформерів. Впровадження застосування наведеного інструменту до навчального процесу дозволить вирішити ряд проблем, пов'язаних з нестачею наглядного матеріалу, адже студенти на домашньому персональному комп'ютері зможуть створювати ті моделі, які їм потрібні на конкретному етапі навчання. Наприклад, при вивченні явища геометричної стереоізомерії студенти на власноруч створених молекулах можуть проаналізувати взаємне розташування груп атомів, що формують ту чи іншу сполуку. При вивченні окремих класів органічних речовин студентам буде надана можливість проаналізувати особливості будови тієї чи іншої системи. Тривимірні моделі дуже зручний інструмент, який дозволить студентам більш ясно зрозуміти роль стеричних факторів при реалізації механізмів реакції. Для реалізації впровадження зазначеного програмного продукту у навчальний процес студентам необхідно дати інформацію про його наявність, користь у процесі самостійного вивчення матеріалу з органічної хімії. Окрім того, викладачі мають передати студентам основні навички роботи з програмою та роз'яснити особливості іiі використання при вирішенні тих чи інших навчальних завдань.

Певної оптимізації, на наш погляд, потребує система контролю якості знань студентів фармацевтичного факультету заочної форми навчання. На даний час для контролю рівня знань найчастіше використовують такі інструменти: відкриті питання, ланцюги перетворень органічних сполук, тестові завдання різного ступеня складності. Враховуючи той факт, що студент часто виконує завдання заочно, всі зазначені вище методи оцінки знань мають певні недоліки. Відкриті питання - досить малоефективні методи контролю, адже студент може просто дублювати інформацію з підручників та Internet-peсурсів, не усвідомлюючи ії значення. Більш ефективними $\epsilon$ завдання у вигляді ланцюгів перетворень органічних сполук, але навіть у цьому випадку не завжди вдається визначити, наскільки студент може використовувати здобуті знання з предмета. Тестові завдання $є$ ефективними лише як експрес-метод визначення знань, що дозволяють виявити наявність певного обсягу інформації у студентів. Чи вміють вони оперувати здобутими даними, з використанням тестового контролю з' ясувати вкрай важко [3]. Ми пропонуємо завдання по ретросинтетичному аналізу [4] та обгрунтуванню методів синтезу органічних сполук як альтернативу існуючим методам контролю знань. В рамках даного завдання студентам буде запропоновано структуру органічної сполуки, для якої потрібно розробити метод синтезу з використанням принципів ретросинтетичного аналізу. На наш погляд, вдале вирішення цієї проблеми підтвердить високий рівень підготовки майбутніх фахівців у галузі фармації.

Висновки: 1. Основними напрямками оптимізації навчального процесу з органічної хімії студентів фармацевтичного факультету заочної форми навчання $€$ впровадження нових підходів на етапах самостійного опрацювання навчального матеріалу та контролю якості знань. 
2. Самостійна робота студентів заочної форми навчання по вивченню органічної хімії може стати більш ефективною при використанні студентами програм молекулярного моделювання.

\section{Література}

1. Медична освіта у світі та в Україні. Додипломна освіта. Післядипломна освіта. Безперервний професійний розвиток / [Ю. В. Поляченко, В. Г. Передерій, О. П. Волосовець та ін.]. -К. : Книга Плюс, 2005. - 384 с.

2. Науменко О. М. Віртуальна хімічна лабораторія як складова інтернет орієнтованої педагогічної технології/ О. М. Науменко // Інформаційні технології і засоби навчання. -2012 . - № 5 (31).
3. Завдання з розробки методів синтезу органічних сполук, з використанням підходів ретросинтетичного аналізу, є ефективним підходом до контролю якості знань з органічної хімії студентів фармацевтичного факультету заочної форми навчання.

3. Унгурян Л. М. Застосування тестової системи оцінки знань у навчальному процесі / Л. М. Унгурян, М. С. Образенко // Медична освіта. -2011. - № 3. - С. 20-22.

4. Титце Л. Препаративная органическая химия: Реакции и синтезы в практикуме органической химии и научно исследовательской лаборатории / Л. Титце, Т. Айхер; пер. с нем. - М. : Мир, 1999. - 704 с. 